\title{
Business Education Teacher-An Instrument for Integrating New Business Education Technologies for Sustainable Development Practice
}

\section{Durojaye Modupe Oluwatoyin}

Tai Solarin College of Education, School of Vocational and Technical Education, Business Education Department, Omu-Ijebu, Ogun State, Nigeria

How to cite this paper: Oluwatoyin, D. M. (2018). Business Education Teacher-An Instrument for Integrating New Business Education Technologies for Sustainable Development Practice. The Educational Review, USA, 2(6), 360-370.

http://dx.doi.org/10.26855/er.2018.06.005

Corresponding author: Durojaye Modupe Oluwatoyin, Tai Solarin College of Education, School of Vocational and Technical Education, Business Education Department, Omu-Ijebu, Ogun State, Nigeria.

\begin{abstract}
The world is changing. The world of the 18th and 19th centuries is different from the world of today. This dynamism is also blowing across every sphere of human existence. New developments in businesses and new technologies have fueled rapid changes in the world of business as the modern office no longer uses the traditional methods of collecting, processing, disseminating and sorting of information as well as doing business generally. This stems from the important role it plays in the national economic and business development. Information technology (IT) has become an important tool for the achievement of the needed globalization. It enhances the flow of information across boundaries of the nations with little regards to the geographical barriers. This implies that the business education teachers should be adequately prepared in order to integrate the information technology applications with business education. This integration would prepare the Nigerian citizens to face the challenges of the application of these new technologies in the national business activities. Education across the world is now centered on new technologies, hence business education cannot ignore the importance of utilization of new technologies. Therefore, this study examines the elements of globalization and information technology on business education in Nigeria. It observes that teachers are the instruments for integrating technology in business education and concludes that without adequate training, technology-based re-orientation, and up-grading to imbibe new ideas engendered by the new technologies, it might be difficult to achieve sustainable development in the business education sector in Nigeria.
\end{abstract}

\section{Keywords}

Information Technology, Globalization, Integration, Dynamism

\section{Introduction}

The influence of information technology on business education over the past five years cannot be over emphasized. However, business educators have always been flexible to such changes even though such transitions are not always immediately welcomed universally (Afari-Kumah \& Tanye, 2009, Bladergroen et al, 2012). From the typewriter to the transistor, business curriculum which allows one to develop expertise in specific areas of business from accounting, management and operations to information management, marketing and finance has continually shaped itself to meet the needs of business. As a result, the success and survival of business education constantly depends on its ability to adapt and keep pace with the needs of its customers (Brown and Warschauer, 2006). These changes present challenges for both the students and the teachers. Nevertheless, 
it is the business educator that must be willing to adapt and manage these challenges to ensure successful programs for the future. It is essential that the new technologies be a useful and vital component of the business education curriculum if business education across the country is to continue to meet the needs of its students (IIoanusi and Osuagwu, 2009). Computers are an integral part of 21st century businesses and for this reason, it is important for current and prospective business educators, students and business managers to use them like pencil and paper (Oye et al, 2012).

Before computers were available, business administrators either had to meet face to face with other organization members (employees or department managers) or talk via phone, which in cases of mass messages (toward employees or shareholders for example) was impossible. Traditional mail is a costly and slow option, but email is a faster, safer and more accurate alternative. Furthermore, teleconferencing can make a business meeting happen, irrespective of the location of each board member (Ogunsola and Aboyade, 2005).

Business owners deal with a large quantity of data, from financial documents to production efficiency reports and information on competing firms. Therefore, it is mandatory for a manager to spot any information he wants instantly and traditional storage drawers don't offer search engines. Computers also give the ability to keep backups of important files, so in case something goes wrong, the manager has a safety cushion (Ekundayo, 2009).

Apart from the adrenaline business management can provide, business managers also have to do tedious or repetitive tasks. For example, composing financial reports needing only changes in the figures or spotting certain parts of business contracts. Computers help streamline the information, which allows managers to focus on more important management tasks (deal with departments' expenditure or trading partners' satisfaction for instance) and raise their productivity (Davis et al, 1989).

Electronic mail does not consume paper, electronic files do not need maintenance and teleconferences don't require a room for guests and entertainment. With computers, managers can cut small costs which in everyday practice account for a considerable percentage of the total administration costs. This allows the administration to concentrate on the more important issues, such as a new market research or an improved network of communication between members of the company (Rieber and Welliver, 1989).

With the introduction of computers, the study of business education was changed forever. Using computers and software, businesses use information technology to ensure that their departments run smoothly. Information technology is being used in a number of different departments including human resources, finance, manufacturing, and security (Keegwe et al, 2008).

With the use of information technology, businesses have the ability to view changes in the global markets faster than they usually do. They purchase software packages and hardware that helps them get their job done. Most large businesses have their personal information technology department designed for software and hardware updates (Vega and Vanessa, 2013).

The basic objectives of business education have not changed. Business education is still about preparing students for the world of business (IIoanusi and Osuagwu, 2009). In fact, meeting the expectations and needs of the next generation is an important reason why business educators should embrace the use of information technology. Just as in past history when significant advances affected businesses, educators again have an opportunity to broaden and improve their programs. It is imperative that business curriculum always be flexible enough to change to meet the needs of business (Johnson et al, 2007).

\section{The Need for Technology Integration in Tertiary Education}

An increasing reliance on the use of electronic instructional media in teaching and learning has recently become a worldwide trend (Akindoju et al, 2014, COM, 2003). The integration of technology into teaching and learning in the educational sector has been described by Maithya and Ndebu (2011) as an innovation which agrees with Clarke (2003), who describes as inevitable the adoption of technology for universities. The importance of electronic instructional media in leveraging the potential of emerging technologies need not be overemphasized because worldwide, academics are increasingly dependent on different 
types of information technologies for teaching, research and consultancy services in the universities (Odero-Musakali \& Mutula 2007). The ubiquitous nature of technological advancement has transformed the educational landscape as a result of convergence of media and technologies (Asnafi, 2005) and the possibilities offered by Internet (Abaidoo \& Arkorful 2014). These developments puts pressure on academics to discontinue from using the chalk and lecture method of teaching in preference for electronic instructional media. Academics in response now have to design a learning environment that can accommodate and quench the thirst of technology-savvy for students in their endeavours to learn.

Universities require adequate Information Technology facilities to augment face-to-face teaching. Students are expected to have academic networking with their student counterpart across the globe. Current learning materials are required from lecturers to promote the quality of education and their product. University academic staff should be able to compete with their colleagues globally. However the concern is whether the university academic staff are prepared to integrate the technology that is feasible to them into effective lessons for their students. ((Brown and Warschauer, 2006, Keegwe et al, 2008, Ma and Streith, 2005).

The level of enlightenment on which Information Technology can be integrated in university education is still low. Many lecturers hardly comprehend the benefit of the IT in education. Most of the lecturers acknowledged the fact that internet could be browsed as a point of supply of teaching materials (Oyelaran-Oyeyinka and Adeya, 2004). Research show that, in Nigeria, $58.5 \%$ use computers for word processing, 32.2\% use it for spreadsheet, data processing, $20.5 \%$ use it for programming and $66.9 \%$ use it for e- mail/Internet while $9.4 \%$ use the computer for other purposes apart from the aforementioned (Oyelaran-Oyeyinka and Adeya, 2004).

An estimation of $90 \%$ of educational institutions in Nigeria are in the emerging phase of ICT, $7 \%$ in the application phase, and $3 \%$ in the infusing and transforming phases. Information Technology is therefore in its infancy in Nigeria. Nigeria though, has a great advantage because there are many Nigerian ICT experts in the Diaspora. However, no concerted effort has been made to harness this potential to accelerate and sustain IT development in the Nigerian educational settings (IIoanusi and Osuagwu, 2009).

\section{Information Technology in Business Education}

The pace of change brought about by new technologies has had a significant effect on the way people live, work, and study worldwide. New and emerging technologies challenge the traditional process of teaching and learning, and the way business education is managed. Information technology, while an important area of study in its own right, is having a major impact across all curriculum areas (Joy \& Ishikaku, 2012). Easy worldwide communication provides instant access to a vast array of data, challenging assimilation and assessment skills (Afari-Kumah \& Tanye, 2009).

Rapid communication, plus increased access to information technology in the home, at work, and in educational establishments, could mean that learning becomes a truly lifelong activity — an activity in which the pace of technological change forces constant evaluation of the learning process itself (Keengwe, 2007).

The information society challenges the education system. In recent years, the speedy, effective and global communication of knowledge has created a new foundation for co-operation and teamwork, both nationally and internationally. The increasing role played by information technology in the development of society calls for an active reaction to the challenges of the information society (Afari-Kumah \& Tanye, 2009).

\section{Prospects of Information and Communication Technology (ICT) In Business Education}

Information and communication technology when aptly implemented in Business Education programme will result to numerous benefits to both the learners and the teachers towards ensuring quality instructions in Business Education. Through the 
application of Information and Communication Technology Students' interest would be sustained and ideas concretized using different resources based on the preference of each student. Slow and fast learners would benefit from the Instructional approach as the process could be repeated several times to accommodate individual differences of the students (Okebukola, 1997).

Brewton (2002) affirmed that the use of information and communication technology in Teaching and learning aid the in-depth understanding of Business concepts and ideas. ICT when applied as teaching devices would improve the individualization of teaching and learning which is lacking in most of our class rooms due to large students-teacher ratio (Brewton, 2002).

The application of Information and Communication Technology would develop teachers and students business ability, concept and attitude. Well written instructional packages to complement the efforts of business teachers and students, especially the poorly skilled/equipped students to develop effective business attitudes and concepts are achievable through ICT. Learning of business education depends on the availability and organization of materials, equipment, media and technology (Akpan, 2003). Information and communication Technology would enhance the teaching of business concepts to the learner at every corner of the globe.

With ICT, students individually or collectively can be lectured or instructioned on different business concepts delivered by business Experts from different parts of the world using varied pedagogical approaches and resources. Teacher and students within a short period would have access to current textbooks, reference books and large volume of current information using internet. This would enhance knowledge sharing, quality of knowledge, authentic and unique knowledge among students and teachers (Akpan, 2003). Ezeliora (2005) affirmed that with ICT, teachers and students within a very short period of time would be acquainted with current textbooks and information. Information and Communication Technology holds out the opportunity to revolutionalize archaic methods, expand access to quality education and improve the management of educational system (World Bank Report, 2002).

Through ICT, teachers, and students of Business Education, libraries and schools in different parts of the globe would communicate with one another and share information to enhance business understandings. Also students and teachers can view documents in richly formatted texts and pictures, connect colleagues, scholars, friends and resource persons in almost all parts of the globe (Akpan, 2003). This would provide the teachers and learners with the opportunities to read modified comprehensive output and to produce or write modified comprehensible output with the help of the internet. This will promote effective communication among students, teachers, peers and provide expansive feedback. Information and communication technology will also enhance educational efficiency (Babajide and Bolaji, 2003).

Through ICT, business education students will be able to seek explanations, compare experiences, reason and learn many concepts in school curriculum. This will also enhance problem-solving skills among students. Information and Communication Technology will offer business educators and students the opportunity to improve greatly on their research techniques as it will act as pathfinder to all researchers on how to write, present and obtain information for their research projects. The problems of searching through library cards and catalogs will no longer be an obstacle through the extensive application of ICT (Bassey et al, 2007).

\section{Significance of Computer Technology in Education and Business}

Computers have changed the way we work, be it any profession. Therefore, it is only natural that the role of computers in education and business has been given a lot of importance in recent years (Ajayi and Ekundayo, 2010). The vital role played by Computers in every field cannot be overemphasized. They aid industrial processes, they find application in business; they are the reason why software industries developed and flourished and they play an important role in education. This is also why the education system has made computer education a part of school curriculum. Considering the use of computer technology in 
almost every sphere of life, it is important for everyone to have at least the basic knowledge of using computers (Collis, 2002). Computer technology has had a deep impact on the education sector. Thanks to computers, imparting education has become easier and much more interesting than before. Computers enable quick processing of data with very little or no chances of errors in processing (Jonassen and Reeeves, 1996). Networked computers aid quick communication and enable web access. Storing documents on computers in the form of soft copies instead of hard ones helps save paper. The advantages of computers in education primarily include:

- Storage of information

- Quick data processing

- Audio-visual aids in teaching

- Better presentation of information

- Access to the Internet

- Quick communication between students, teachers and parents

Computer teaching plays a key role in the modern education system. Students find it easier to refer to the Internet than searching for information in fat books. The process of learning has gone beyond learning from prescribed textbooks. Internet is a much larger and easier-to-access storehouse of information. When it comes to storing retrieved information, it is easier done on computers than maintaining hand-written notes (McCausland et al, 1999).

Online education has revolutionized the education industry. Computer technology has made the dream of distance learning, a reality. Education is no longer limited to classrooms. It has reached far and wide, thanks to computers. Physically distant locations have come closer due to Internet accessibility. So, even if students and teachers are not in the same premises, they can very well communicate with one another. There are many online educational courses, whereby students are not required to attend classes or be physically present for lectures (More and Kearsley, 1996). They can learn from the comfort of their homes and adjust timings as per their convenience.

Computers facilitate effective presentation of information. Presentation software like PowerPoint and animation software like Flash among others can be of great help to teachers while delivering lectures. Computers facilitate audio-visual representation of information, thus making the process of learning interactive and interesting (More and Kearsley, 1996). Computer-aided teaching adds a fun element to education. Teachers hardly use chalk and board today. They bring presentations on a flash drive, plug it into a computer in the classroom, and the teaching begins. This makes the otherwise not-so-interesting lessons become interesting due to audio-visual effects. Due to the visual aid, difficult subjects can be explained in better ways. Things become easier to follow all because of the use of computers in education (Oliver and Short, 1997).

The Internet plays a very important role in education. As it is an enormous information base, it can be harnessed for retrieval of information on a variety of subjects. The Internet can serve as a reference point to information on different subjects which both the teachers and students can benefit from. Teachers can make reference to it for additional information and references on the topics to be taught. Students also can refer to web sources for additional information on subjects of their interest. The Internet also helps teachers set test papers, frame questions for home assignments and decide project topics (Shavinina, 2001). And the importance of the internet is not limited to academics. Teachers can use web sources for ideas on sports competitions, extracurricular activities, picnics, parties and more (Young, 2002).

Computers enable storage of data in the electronic format, thereby saving paper. The memory capacities of computer storage devices are in gigabytes which enables them to store huge chunks of data. Moreover, these devices are compact (Soloway and Pryor, 1996). They occupy very less space, yet store large amounts of data. Both teachers and students benefit from the use of computer technology. Presentations, notes and test papers can be stored and transferred easily over computer storage devices. Students also can submit homework and assignments as soft copies. The process becomes paperless and this goes a long way 
in saving paper. The electronic format also makes data storage more durable. Electronically erasable memory devices can be used repeatedly. They offer robust storage of data and reliable data retrieval (Stephenson, 2001).

In an age of booming technology, running a business without computers is like trying to breathe without lungs. Like it or not, technology has become an integral part of the way business is done. Even if you perform services or provide products such as dry cleaning and hairstyling, which are not technology related in and of themselves, you may find that without a computer, it's difficult to place orders with suppliers or pass information to your accountant (Young, 2002).

Retail and wholesale business have come to increasingly rely on the advanced ability of computers to keep track of inventory and assist in ordering more when stocks get low. However, businesses of all sizes use inventory management and point of sales systems to do smaller scale versions of the same thing (Aribisala, 2006).

While it's still possible to find a typewriter at a garage sale, the days of typed papers and documents are completely over. Word processing is a must in today's business environment (Babajide and Bolaji, 2003). Not only are computers the medium for document creation, but the ability to email and share documents electronically has become central to the editing, approval and delivery process. These documents can be created with the use of such programs as PowerPoint, as this is the standard for modern day businesses (Bandele, 2006).

A business that does not make use of electronic communications, particularly the email, closes off one of the largest communication channels today. Customers, clients, vendors and business partners use email to make contact and transact business. Some companies go beyond email and actually encourage the use of in-house instant messaging as a method of communications between employees and departments (Ofodu, 2007).

Access to the internet is the communication lifeline for any business. Internet-enabled computing allows you to receive orders from customers, place orders with suppliers, research businesses, explore business ideas, communicate with government agencies and even manage your business' banking. In addition, online presence with at least a website is critical to legitimizing a business. Many companies go further and participate in social networking sites for marketing and branding purposes Okebukola, 1997).

For businesses that have more than one site or branch, then multi-site networking provides tremendous benefits for accounting, standardizing and managing the multi-faceted operations of such businesses (Ajisafe, 2014). Many companies use point of sale systems to ensure standardized operations within a chain of stores or sites. Companies that sell similar products or services in multiple locations find that computer systems help them keep track of revenues, costs and their supply chain from a central office. This allows a centralized management team to get reports on any or all sites and get a macro-view of the business when needed (Asnafi, 2005).

\section{Tertiary Applications of Information Technology in Education}

In the era of technology, Information Technology aids plenty of resources to enhance the teaching skills and learning ability. Information Technology now makes it is easy to provide audio visual education. Through it, learning resources are being expanded. Now with this vivid and vast technique as part of the IT curriculum, learners are encouraged to regard computers as important tools to be used in all aspects of their studies (Marwan, 2008). In particular, they need to make use of the new multimedia technologies to communicate ideas, describe projects, and order information in their work (Afari-Kumah and Tanye, 2009).

Information Technology has provided immediacy to education. Now in the year of computers and web networks the speed of knowledge impartation is quite fast and one can be educated anywhere at any time. New IT has often been introduced into well-established patterns of working and living without radically altering them. For example, the traditional office, with secretaries working at keyboards and notes being written on paper and manually exchanged, has remained remarkably stable, even 
if personal computers have replaced typewriters (Marwan, 2008).

Now in the year of computers and web networks the pace of imparting knowledge is fast and one can be educated without any limitation. One can study whenever he wills irrespective of whether it is day or night because of the popularity and wide acceptance Information Technology (Oye et al, 2012).

Information Technology has now made it easy to study as well as teach in groups or in clusters. It is now easy to learn online and unite together to do the desired task. Efficient postal systems, the telephone (fixed and mobile), and various recording and playback systems based on computer technology all have a part to play in educational broadcasting in the new millennium. Children in the developed countries are now familiar to the Internet and its Web sites, likewise educational elites elsewhere, but it remains of little significance to very many more, who lack the most basic means for subsistence (Oye et al, 2012).

Audio-Visual Education, planning, preparation, and use of devices and materials that involve sight, sound, or both, for educational purposes. Among the devices used are still and motion pictures, filmstrips, television, transparencies, audiotapes, records, teaching machines, computers, and videodiscs. The growth of audio-visual education has reflected developments in both technology and learning theory (Oyelaran-Oyeyinka and Adeya, 2004).

Studies in the psychology of learning suggest that the use of audio-visuals in education has several advantages. All learning is based on perception, the process by which the senses gain information from the environment. The higher processes of memory and concept formation cannot occur without prior perception. People can attend to only a limited amount of information at a time; their selection and perception of information is influenced by past experiences. Researchers have found that, other conditions being equal, more information is taken in if it is received simultaneously in two modalities (vision and hearing, for example) rather than in a single modality. Furthermore, learning is enhanced when material is organized and that organization is evident to the student (Oyelaran-Oyeyinka and Adeya, 2004).

These findings suggest the value of audio-visuals in the educational process. They can facilitate perception of the most important features, can be carefully organized, and can require the student to use more than one modality (Bladergroen et al, 2012).

Internets support thousands of different kinds of operational and experimental services one of which is online library. We can get plenty of data on this online library (Brown and Warschauer, 2006).

Teachers and learners in particular need to make use of the new multimedia technologies to communicate ideas, describe projects, and order information in their work. This requires them to select the medium best suited to conveying their message, to structure information in a hierarchical manner, and to link together information to produce a multidimensional document (Joy and Ishikaku, 2012).

The term distance learning was coined within the context of a continuing communications revolution, largely replacing a hitherto confusing mixed nomenclature - home study, independent study, external study, and, most common, though restricted in pedagogic means, correspondence study. The increased demand for access to educational facilities and innovative communication technology has been increasingly exploited in face of criticisms that distance learning is an inadequate substitute for learning alongside others in formal institutions. A powerful incentive has been reduced costs per student. At the same time, students studying at home themselves save on travel time and other costs (Keegwe et al, 2008).

\section{Benefits of Technology Integration to Teachers and Students of Business Education}

According to Falobi (2014), blending technology with face-to-face teacher time generally produces better outcomes than face-to-face or online learning alone. Research is currently limited on the specific features of technology integration that improve learning. Meanwhile, the marketplace of learning technologies continues to grow and vary widely in content, quality, implementation, and context of use (IIoanusi and Osuagwu, 2009). 
What matters most to implementing mobile learning is how students and teachers use technology to develop knowledge and skills and that requires training. Successful technology integration for learning goes hand in hand with changes in teacher training, curricula, and assessment practices. Many research studies have found that most students prefer learning with technology, which in turn leads to a better attitude towards learning. The students with special needs similarly did better on computer based tests and nearly all recommended the program for other students (Saba and Anthony, 2009).

The use of Information Technology by teachers can keep students focused for longer periods of time. The use of computers to look up information/ data is a tremendous time saver, especially when used to access a comprehensive resource like the Internet to conduct research. This time-saving aspect can keep students focused on a project much longer than they would with books and paper resources, and it helps them develop better learning through exploration and research (Huneycutt and Timothy, 2015). It is a part of the modern world, and is becoming more and more ubiquitous in our lives every year. It is also a proven method for improving learning. There is strong evidence pointing towards technology leading to better results on standardized tests; however the real emphasis should not be on how it improves test scores, but on how it benefits student learning; how it enables those who are not able to perform at their peak in traditional classrooms to do better; how it motivates students to learn and gives them a more positive attitude towards education; how it can individualize learning by giving feedback; how it can act as a catalyst for change towards more student centered learning; and how it better prepares the youth of today with technical, communicative, interpersonal and creative skills. The question we should be asking is not whether or not technology should be in business education, but what can we do to remove barriers so as to further the integration of technology into our schools. Hence, one area in which more research must be done is on how to best move towards more student centered learning with technology and how to best overcome barriers to doing so (Saba and Anthony, 2009).

\section{The Nigerian Perspective}

The introduction of ICT into the Nigerian universities has obviously changed the way education is being conducted. It paved the way for a new and technical approach, where students are expected to play more active role than before (i.e. getting more involved in the learning process, being active participants of knowledge creation not mere recipients of knowledge). Using information and known ICT tools in education, students should be able to communicate, create preservatives in PowerPoint, and interact with colleagues and teachers using technology (Yusuf, 2005).

Nigeria as a nation is yet to make available and use extensively ICT in the transformation of its educational system. The benefits of internet use in education was indicated by Ololube (2007, 2008), and he also found positive and moderately high achievement at all educational level, from computer use in school subjects, which allows students to focus on strategies and interpretation of answers rather than spend time on tedious computational calculation (Esene, 2009). It is then widely believed that the use of internet in the educational and business sector in a developing nation like Nigeria would help bridge the information barrier between the developed and other developing nations. However, improved access does not result in improved utilization in educational institutions (Ololube, 2007).

It is often observed in most higher education circles in Nigeria that some institutions are better endowed than others in terms of, for example, the number, qualification and experience of the faculty and the availability of books and instructional technology materials (Ololube, 2008). Only a few sector of the Nigerian economy that have progressed beyond the emerging phase in the utilization of information technology. An estimated $90 \%$ of the Nigerian educational institutions are in this emerging phase while 7\% are in the applying phase, and 3\% in the infusing and transforming phases (IIoanusi and Osuagwu, 2009). The better endowed institutions tend to and eventually produce better results compared to their counterparts. Some faculties are simply more skillful than others. This result underlines the fact that, although substantial instructional resources may affect academic outcomes through their impact on the quality of the classroom environment, the interaction between faculty members and their 
students also play an important role (Ololube et al, 2009).

Computer technologies are perhaps the most fundamental information and communication technology tools in use today. With increasing pressure on the Nigerian higher educational and business institutions to "do more with less", ICT can help to maintain or improve the quality of services in these sectors while at the same time significantly reducing cost (Ololube et al, 2009).

There have been extensive studies on the factors influencing the adoption and integration of ICTs for educational purposes among others (Oladokun, 2012). In spite of the benefits derived from ICT use, Nigeria is still disadvantageous over their african counterparts elsewhere (Ololube et al, 2009).

Also, despite intensive studies on the process, impact and decline of technology use in instructional teaching in IT disciplines, the unavailability of technology laboratories for students and faculties in the Nigerian higher educational systems and a limited instructional use of IT generally in teaching processes, an effective policy has still not been put forward to remedy the situation (Ifinedo, 2005, Ololube, 2007, 2008, Egboka, 2012).

\section{Conclusion}

As teaching and learning with technology is growing fast, it is very important to question whether the increased investment in ICT is translating into actual use and improved educational outcomes but despite the perceived benefits in the use of ICT in schools, there are a lot of factors inhibiting the successful application of ICT in the Nigerian tertiary institutions. In order to fit into the new scientific order, it is necessary for Nigerian institutions and individuals to develop a society and culture that places a high demand on information and communication technology.

It can therefore be concluded from this study that ICT facilities are not readily available in most Nigerian schools and that there is a low level of ICT utilization in our tertiary institutions and for this reason, Nigeria must re-focus on her educational system and integrate information and communication technology (ICT) into Business Education Curriculum to enhance its contents in order to meet the changes in the global market, office automation and access to quality education.

\section{References}

Abaidoo, N., \& Arkorful, V. (2014). Adoption and Effective Integration of ICT in Teaching and Learning in Higher Institutions in Ghana. Retrieved 15 September 2015 from http://www.ijern.com/journal/2014/December-2014/35.pdf.

Abdul-Salaam, A. O. (2007). The Role of Information and Communication Technologies in Nigeria Educational System. J. Sci. and Sci.

Afari-Kumah, E., \& Tanye, H. A. (2009). Tertiary Students' View on Information and Communications Technology Usage in Ghana. Journal of Information Technology Impact, 9(2), 81-90.

Bingimlas, K. A. (2009). Barriers to the Successful Integration of ICT in Teaching and Learning Environments: A Review of the Literature. Eurasia Journal of Mathematics, Science \& Technnology Education, 5(3), 235-245.

Ajayi IA, Ekundayo, H. T. (2010). Contemporary Issues in Educational Management. Bolabay Publication Lagos Nigeria.

Ajisafe, O. E. (2014). Fostering Utilization of Information and Communication Technology Skills among Students of Business Education. Proceedings of the 22nd Conference of the Association of Business Educators of Nigeria (pp. 171 - 174).

Akindoju, O. G., Nwagwu, R. N., Akintoye, H. O., Avoseh, J. O., \& Aregbede, S. (2014). Adequacy and Utilisation of Information and Communication Technologies by Computer Science Lecturers in Tertiary Institutions in Lagos State, Nigeria. International Journal for Innovation Education and Research, 2(2), 60-67.

Akpan, I. U. (2003). Information Technology Revolution: Challenges and Opportunities. Business Education Journal, 3(2), 110-113.

Aribisala, J. O. (2006). Role of Information and Communication Technology in Globalization. In gagu AA (ed.) Information and Community Technology and Computer Applications. Abuja: Pan of Press.

Asnafi, A. R. (2005). What Is E-learning and Where Is the Place of Virtual Libraries in This Process? Faslname-ye Katab, 16(3): 133-148.

Babajide, V. F. T., \& Bolaji, O. A. (2003). Perception of Lecturers and Service Teachers towards the Use of Communication Media in Teaching Pure and Applied Science related Discipline. In 44th Annual STAN Conferencing Proceeding.

Bandele, S. O. (2006). Development of Modern ICT and Internet System. In Agagu, A.A (ed). Information and Communication Technology 
and Computer Applications. Abuja: Panof Press.

Bassey, U. C., Uwoven, G. U., Akuegwu, B. A., Udida, L. A., \& Ntukidem, E. P. (2007). Nigerian Graduating Students access to E-learning Technology. Implications for Higher Education Management. Business Education Journal, 6(2), 120-128.

Bladergroen, M., Chigona, W., Bytheway, A., Cox, S., Dumas, C., \& Zyl, I. V. (2012). Educator Discourses on ICT in Education: A Critical Analysis. International Journal of Education and Development Using Information and Communication Technology, 8(2), $107-119$.

Choudhary, R., \& Choudhary, J. R. (2013). Use of ICTs: To Promote Good Teaching and Learning Practices in Higher Management Education. International Journal of Emerging Technology and Advanced Engineering, 3(6), 288-294.

Brewto, C. C. (2002). Using the Internet to Enrich Science Education. Lecture at the 41 Annual Conference of Science Teacher Education Association (STAN).

Brown \& Warschauer. (2006). From the University to the Elementary Classroom: Students' Experiences in Learning to Integrate Technology in Instruction. Journal of Technology and Teacher Education. 14(3), 599-621.

Clarke, C. (2003). Towards a Unified E-learning Strategy. Department for Education and Skills, UK, Consultation Document. Retrieved 15 April 2014 from http://www.dfes.gov.uk/elearningstrategy/strategy.stm.

Collis, B. (2002). Information Technologies for Education and Training. In: Adelsberger H, Collis B \& Pawlowski J (Eds.) Handbook on Technologies for Information Training. Berlin: Springer Verlag.

COM. (2003). Choosing to Grow: Knowledge, Innovation and Jobs in a Cohesive Society; Report to the Spring European Council, 21 March 2003 on the Lisbon Strategy of Economic, Social and Environmental Renewal. Retrieved 15 June 2014 from http://europa.eu.int/comm/lisbon_strategy/pdf.

Davis, Bagozzi, \& Warshaw. (1989). User Acceptance of Computer Technology: A Comparison of Two Theoretical Models. Management Sience, 35, 982-1003.

Egboka, P. N. (2012). The Status of Information and Communications Technology (ICT) in Empowering Policy Implementation in Universities in South East Zone of Nigeria. International Journal of Educational Research and Development, 8(2), 231-236.

Ekundayo, M. S. E., J. M. (2009). Capacity Contraints in Developing Countries: A Need for More E-learning Space? The Case of Nigeria. In Proceeding Ascilite Auckland.

Esene, R. A. (2009). Research in Education. Agbor: Royal Pace Publications.

Ezeliora, B. (2005). Problems Affecting the Effective Use of Information Technology in the Teaching and Learning of Chemistry. Interdisciplinary Journal (INTEJ,) 4 (1), 26-29.

Falobi, O. V. (2014). An Investigation into the Impact of ICT on Commercial Students' Academic Performance in Public Schools in Lagos State. Journal of Association of Business Educators of Nigeria, 1(1) 48-154.

Huneycutt, T. (2015). Technology in the Classroom: The Benefits of Blended Learning. National Math + Science Initiative. Retrieved 10 March 2015.

Ifinedo, P. (2005). Measuring Africa's E-readiness in the Global Networked Economy: A Nine-Country Data Analysis. International Journal of Education and Development Using Information and Communication Technology, 1(I), 53-71.

IIoanusi, \& Osuagwu. (2009). ICT in Education: Achievement so Far in Nigeria. Research, Reflection and Innovation in Integrating ICT in Education.

Johnson, O. A., (2007). Enhancing Quality in Higher Education through Information and Communication Technology in Nigeria, in Access, Equity and Quality in Higher Education, J. B. Babalola, Akpan, G. O., Ayeni, A. O. \& Adedeji, S. O., Editor. 2007, NAEAP Publication.

Jonassen, D., \& Reeeves, T. (1996). Learning with Technology: Using Computers as Cognitive Tools. In: Jonassen D (eds). Handbook Res. Educ. Educ. Commun. Technol., 693-719.

Joy, N., \& Ishikaku, E. (2012). Integration of Information and Communication Technology (ICT) in Teacher Education for Capacity Building. Journal of Education and Practice, 3(2), 68-73.

Jung, I. (2005). ICT-Pedagogy Integration in Teacher Training: Application Cases Worldwide. Educational Technology \& Society, 8(2), 94-101.

Keengwe, J. (2007). Faculty Integration of Technology into Instruction and Students' Perceptions of Computer Technology to Improve Student Learning. (L. M. Jeffrey, Ed.) Journal of Information Technology Education, 6, 169-180.

Keegwe, O., \& Wachira, P. (2008). The Use of Computer Tools to Support Meaningful Learning. AACE Journal, 16(1), 77-92.

Ma, A., R., \& Streith, K. O. (2005). Examining User Acceptance of Computer Technology: An Empirical Study of Student Teachers. Journal of Computer Assisted Learning, 21(6), 387-395.

Maithya, R. \& Ndebu, S. (2011). Factors Influencing Effective Use of ICT in Teacher Education: A Case of Kenya Technical Teachers College. Quality Education for Societal Transformation. International Conference on Education, Kenyatta University Conference Centre. Nairobi. Kenyatta University and Syracuse University. 
Marwan, A. (2008). Teachers' Perceptions of Teaching with Computer Technology: Reasons for Use and Barriers in Usage. Retrieved May 10, 2014, from http://www.itdl.org/Journal/jun_08/article04.htm.

Mingaine, L. (2013). Skill Challenges in Adoption and Use of ICT in Public Secondary Schools, Kenya. International Journal of Humanities and Social Science, 3(13), 61-72.

McCausland, H., Wache, D., \& Berk, M. (1999). Computer Literacy: Its Implications and Outcomes. A Case Study from The Flexible Learning Centre. University of South Australia.

More, M., \& Kearsley, G. (1996). Distance Education: A Systems View. Belmont, CA: Wadsworth

Odero-Musakali, D., \& Mutula, S. M. (2007). Internet Adoption and Assimilation in Kenyan University Libraries. Library Review, 56(6), 464-475.

Ofodu, G. O. (2007). Nigeria Literary Educators and Their Technological Needs in A Digital Age. Educ. Focus, 1(1), 22-30.

Ogunsola, \& Aboyade. (2005). Information and Communication Technology in Nigeria: Revolution or Evolution, 11(1), 7-14.

Okebukola, P. (1997). Old, New and Current Technology in Education. UNESCO Africa. 14(15), 7-18.

Oladokun, L. (2012). Exploring the Benefits of ICT in Educational Sector, National Information Technology Agency, Abuja: Government Press.

Oliver, R., \& Short, G. (1997). The Western Australian Telecentres Network: A Model for Enhancing access to Educational Training in Rural Areas. Int. J. Educ. Telecommun., 2(4), 311-328.

Ololube, N. P. (2007). The Relationship between Funding, ICT, Selection Processes, Administration and Planning and The Standard of Science Teacher Education in Nigeria.Asia-Pacific Forum on Science Learning and Teaching, 8(1), Article 4. [Online]http://www.ied.edu.hk/apfslt/v8_issue1/ololube/.

Ololube, N. P. (2008) Computer Communication and ICT Attitude and Anxiety among Higher Education Students. In A. Cartelli, (Ed). Encyclopedia of Information and Communication Technology, pp.100-105. Hershey, PA: Idea Group Publishing.

Ololube, N. P., Eke, P., Uzorka, M. C., Ekpenyong, N. S., \& Nte, N. D. (2009) Instructional Technology in Higher Education: A Case of Selected Universities in The Niger Delta. Asia-Pacific Forum on Science Learning and Teaching, 10(2), Article 7.

Oye, N. D., Iahad, N. A., \& Ab.Rahim, N. Z. (2012). The Impact of UTAUT Model and ICT Theoretical Framework on University Academic Staff: Focus on Adamawa State University, Nigeria. International Journal of Computers \& Technology, 2(2).

Oyelaran-Oyeyinka, \& Adeya. (2004). Dynamics of Adoption and Usage of ICT in African Universities: A Study of Kenya and Nigeria. Elsevier, 24, 841-851.

Rieber, L. P., \& Welliver, P.W. (1989). Infusing Education Technology into Mainstream Educational Computing. International Journal of Instructional Media, 16, 21-32.

Saba, A. (2009). Benefits of Technology Integration in Education, (in PDF).

Shavinina, L. V. (2001). A New Generation of Educational Multimedia: High Intellectual and Creative Educational Multimedia Technologies. In: Vandervert LR, Shavinina LV \& Cornell RA (Eds.), Cyber Education: The Future of Distance Learning. Larchmont, NY: Mary Ann Liebert, Inc, pp.63-82.

Soloway, E., \& Pryor, A. (1996). The Next Generation in Human Computer Interaction. Commun. ACM, 39(4), 16-18.

Stephenson, J. (2001). Learner- Managed Learning an Emerging Pedagogy for Online Learning. Teaching and Learning Online: Pedagogies for New Technologies. London, Kogan Page.

Vega, V. (2013). Technology Integration Research Review: Additional Tools and Programs.

Wang, Q., \& Woo, H. L. (2007). Systematic Planning for ICT Integration in Topic Learning. International Forum of Educational Technology \& Society, 10(1), 148-156.

World Bank Report. (2002). Information and Communication Technologies. A World Bank Group Strategy. Washington DC. The World Bank Group.

Young, J. (2002). The 24-hour Professor. The Chronicle of Higher Education. 48(38), 31-33.

Yusuf, M. O. (2005). Information and Communication Technologies and Education: Analyzing the Nigerian National Policy for Information Technology. International Education Journal, 6(3), 316-321. 